\title{
Rough-Toothed Dolphins (Steno bredanensis) as Predators of Mahimahi (Coryphaena bippurus) $^{1}$
}

\author{
Robert L. Pitman ${ }^{2,3}$ and Charles Stinchcomb ${ }^{2}$
}

\begin{abstract}
We present details of four separate observations of rough-toothed dolphins (Steno bredanensis) apparently preying on adult-sized $(\geq 1 \mathrm{~m})$ mahimahi (Coryphaena bippurus) in the eastern Pacific. We cite similar sightings from Hawai $i$ and some additional behavioral observations (synchronized swimming, food sharing, regular association with flotsam), and suggest that rough-toothed dolphins may be specialized predators on large mahimahi.
\end{abstract}

LitTle is kNOWN about the food or feeding habits of rough-toothed dolphins (Steno bredanensis) (Miyazaki and Perrin 1994). The only report of stomach contents from healthy, wild animals listed "molluscs [i.e., squid] and fish" (Perrin and Walker 1975). Shallenberger (1981) reported that stranded specimens from Hawai'i had fish (silverside, Pranesus insularum; saury, Cololabis adocetus; and a needlefish, Tylosurus crocodilus) and unidentified squid in their stomachs. He cautioned however that these were nearshore (i.e., shallow-water) fish species and may not have been representative prey of healthy dolphins in their usual open-ocean environment (see also Barros et al. 2000). This is especially true for animals that strand outside their usual geographic range (e.g., Ferrero et al. 1994). Specific cephalopods reported in the diet have included Teuthowenia sp. and Tremoctopus violaceus (Clarke 1986). In this note we report on six separate observations of roughtoothed dolphins preying upon adult-sized mahimahi (also known as dolphinfish or dorado [Coryphaena hippurus]), and we argue that $S$. bredanensis may be specifically adapted to taking this species.

Observation no. 1 was made by C.S. at

\footnotetext{
${ }^{1}$ Manuscript accepted 8 February 2002.

2 Southwest Fisheries Science Center, 8604 La Jolla Shores Dr., La Jolla, California 92037.

${ }^{3}$ E-mail: Robert.Pitman@noaa.gov.
}

Pacific Science (2002), vol. 56, no. 4:447-450

(C) 2002 by University of Hawai'i Press

All rights reserved
14:15 Local Mean Time (LMT) on 23 November 1999 and observed from a helicopter for $14 \mathrm{~min}$; the position was $7^{\circ} 57^{\prime} \mathrm{N}, 91^{\circ} 36^{\prime}$ $W$, approximately $670 \mathrm{~km}$ off the west coast of Costa Rica. There were $10 \mathrm{~S}$. bredanensis present and one adult-sized animal was photographed as it swam with a large (ca. $1.5 \mathrm{~m}$ ) mahimahi in its mouth (Figure 1). The fish was still alive during the sighting but swimming feebly and unable to escape. The swimming dolphin released it several times and recaptured it after several seconds each time. Although the other dolphins seemed interested in the fish, only the one dolphin was seen to interact with it. It was not determined if the dolphin(s) actually ate the fish.

R.L.P. made the next three observations from a small inflatable boat on 14 November 2000 while approaching three separate $S$. bredanensis schools to obtain biopsy samples. The sighting locations ranged from 20 to 90 $\mathrm{km}$ off the Pacific coast of Mexico near Acapulco; the sea surface temperature ranged from 29.8 to $30.4^{\circ} \mathrm{C}$.

Observation no. 2 occurred at 07:21 LMT; the position was $16^{\circ} 28^{\prime} \mathrm{N}, 100^{\circ} 34^{\prime} \mathrm{W}$. Three $S$. bredanensis were present and they stayed within $75 \mathrm{~m}$ of a floating piece of plywood throughout most of the observation. The dolphins were evasive and whenever we approached within $50 \mathrm{~m}$ they dove out of sight. At one time, when all three were swimming at the surface, we saw that one was carrying a large fish in its mouth. When we approached the dolphins, they dove and swam away, leaving behind a fresh dead mahimahi that was $5 \mathrm{~m}$ or so underwater and sinking fast. We estimated that the fish was at least 


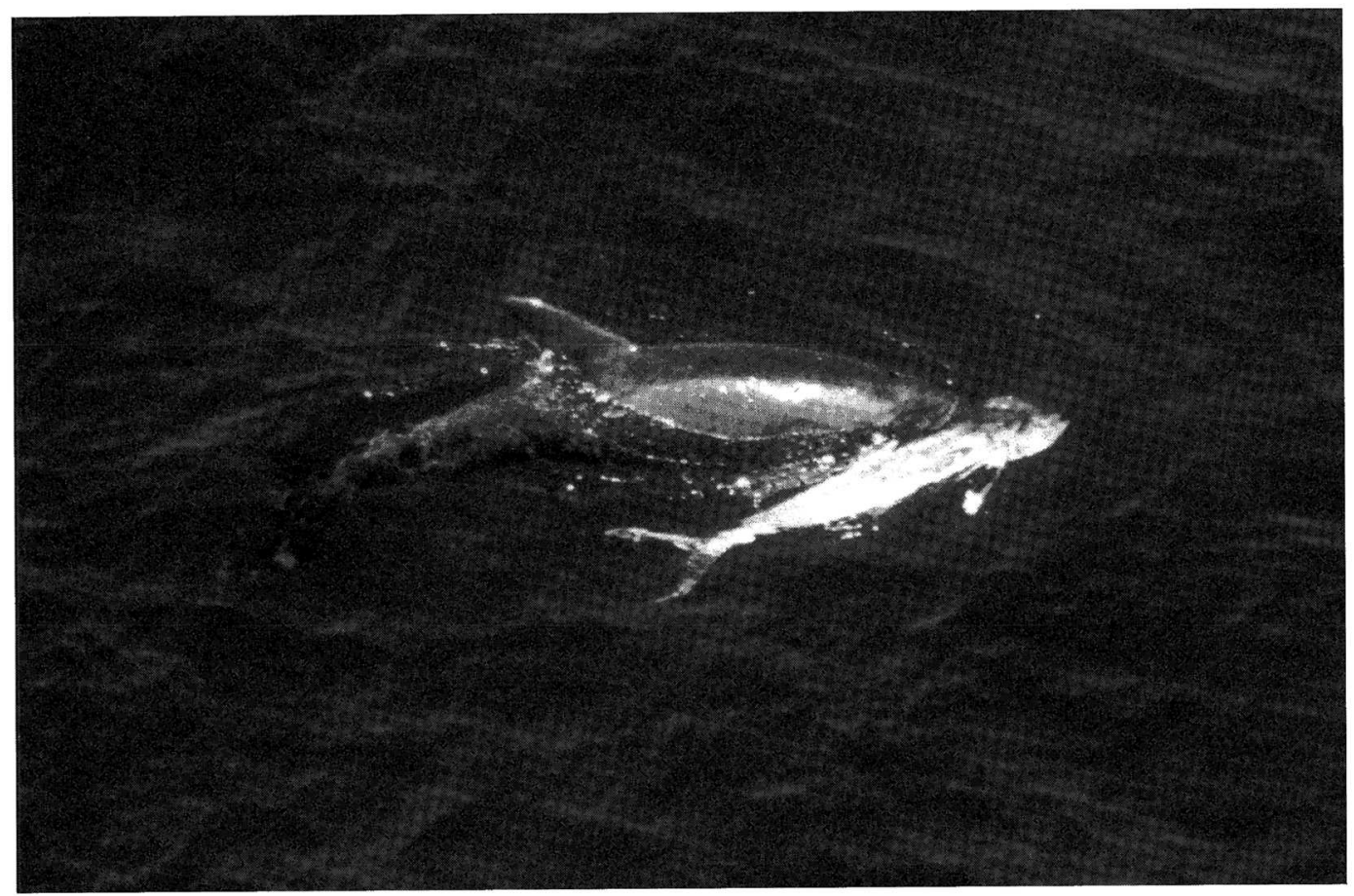

FIgURE 1. A rough-toothed dolphin swimming in the eastern tropical Pacific with a large mahimahi in its mouth (observation no. 1). Photo by C. Stinchcomb.

$1 \mathrm{~m}$ long. As the fish sank deeper we saw the $S$. bredanensis return to it and start nosing it with their beaks. For the next $20 \mathrm{~min}$, as the $S$. bredanensis kept diving and disappearing, and even though they may have traveled as much as $150 \mathrm{~m}$ between surfacings, we found the dead mahimahi back up within $5 \mathrm{~m}$ of the surface and sinking each time we approached the dolphins. There were no obvious signs of injury to the fish and the colors were still vivid, suggesting that it had been dead for a short period of time. At the time it was not clear to us if the dolphins had killed the fish or found it dead, or whether they were planning on eating it or were just playing with it. We left the scene before we were able to make any further observations.

Observation no. 3 occurred at 11:16 LMT; the position was $16^{\circ} 47^{\prime} \mathrm{N}, 100^{\circ} 53^{\prime} \mathrm{W}$. There were approximately $15 \mathrm{~S}$. bredanensis present in two or three subgroups. As we approached one subgroup, one of the dolphins swam several meters below our boat carrying a large (ca. $1.5 \mathrm{~m}$ ) mahimahi crosswise in its mouth. The fish appeared to be freshly dead and had no outward signs of trauma. Although we stayed with this group for almost $45 \mathrm{~min}$, we did not see the fish again.

Observation no. 4 occurred at 15:00 LMT; the position was $17^{\circ} 09^{\prime} \mathrm{N}, 101^{\circ} 15^{\prime} \mathrm{W}$ and involved a school of approximately $20 \mathrm{~S}$. bredanensis. After working with this group for approximately $15 \mathrm{~min}$ we saw one dolphin surface with a mahimahi ca. $1 \mathrm{~m}$ long in its mouth. Although the head and tail were intact, most of the flesh had been stripped off the side of the fish that we could see so that it looked like it had been neatly filleted. The dolphins continued diving in the same location, apparently feeding. In the immediate area we also saw a sailfish (Istiophorus platypterus) (another predator of mahimahi) finning at the surface and apparently agitated by the nearby dolphins (it was raising and lowering 
its sail). We also saw a live mahimahi approximately $1 \mathrm{~m}$ long swimming close to the surface with fresh wounds on its sides where flesh was protruding (it may have been impaled by the sailfish).

In addition to our observations, Brower and Curtsinger (1979) reported two instances of $S$. bredanensis carrying large mahimahi in the waters off Hawai $i$. In the first case there were 10 dolphins in a school and one was carrying a "twenty-pound" mahimahi crosswise in its beak (estimated standard length $=$ $1 \mathrm{~m}$ [Palko et al. 1982]). It dropped the fish and another dolphin picked it up. While the second dolphin was carrying the fish, a third dolphin came by and took the fish, and then it was passed to the original dolphin, which seemed to be the "keeper" of the fish. Although Brower and Curtsinger did not see the dolphins actually eat the fish, they reported that the dolphins were "chewing" on it. Six days later, also off Hawai'i, they saw another $S$. bredanensis carrying a fresh dead mahimahi at the surface. The school it was with was swimming slowly in close formation, and once again there was an apparent "keeper" of the fish. It was feeding on the fish while swimming and it appeared to use the water and its swimming motion as leverage to peel flesh off the fish. The "keeper" allowed other members of the school to take pieces of flesh freely off the fish or take the entire fish for a while.

These observations have relevance for diet studies of rough-toothed dolphins, especially any based on stomach content analysis. Defran and Pryor (1980) reported that newly captive rough-toothed dolphins were observed "to gut and behead all food fish, no matter how small, by smashing them against the water's surface." Similarly, our observation no. 3 and one by Brower and Curtsinger (1979) just described suggest that roughtoothed dolphins may feed on mahimahi mainly by peeling off the flesh, which would leave little in the way of hard parts (otoliths, bones, etc.) for identifying prey species. Also, remains of mahimahi prey, including many of the species of fishes that associate with flotsam, could show up as secondary prey items in $S$. bredanensis stomachs, especially the large and durable otoliths of flyingfish, a major prey item of mahimahi (Palko et al. 1982).

The observations cited here, separated as they were in space and time, indicate that $S$. bredanensis probably preys regularly upon adult mahimahi (mahimahi reach sexual maturity at about $0.5 \mathrm{~m}$ [Palko et al. 1982]; all of the fish we report on were $\geq 1 \mathrm{~m}$ ). There is, however, some additional behavioral, and perhaps morphological, evidence to suggest that rough-toothed dolphins may be specialized mahimahi predators. The behaviors include associating with flotsam and cooperative foraging.

On the open ocean, $S$. bredanensis regularly associates with floating debris (logs, dead whales, wooden pallets, etc. [Leatherwood et al. 1982; pers. obs.]), and it is, in our experience, the only species of cetacean that does so. For example, of $250 \mathrm{~S}$. bredanensis sightings recorded during dolphin survey cruises in the eastern tropical Pacific by the Southwest Fisheries Science Center during the past $25 \mathrm{yr}, 43$ (17\%) were associated with flotsam. Mahimahi is a common predatory fish found throughout tropical and subtropical oceans of the world; it has a geographic range almost identical to that of S. bredanensis (Miyazaki and Perrin 1994), and it also regularly associates with flotsam (Palko et al. 1982). In the eastern tropical Pacific, for example, we often see large mahimahi associated with flotsam, where there can be dozens, sometimes hundreds, of individuals schooling in the immediate area (Au 1991). Although juvenile fishes of a variety of other species also regularly associate with flotsam in the Tropics (Hunter and Mitchell 1966) and are also potential $S$. bredanensis prey, we suggest based on the observations reported here that rough-toothed dolphins may be more interested in the availability of large mahimahi.

Mahimahi are large, fast-swimming fish, and if relatively slow-swimming S. bredanensis is going to be able to capture healthy adults, highly developed, cooperative foraging will probably be required (Connor and Norris 1981). Evidence that $S$. bredanensis cooperatively pursues large individual prey comes from three observations. First, S. bredanensis is one of the few delphinids that regularly 
swims and surfaces synchronously: within larger schools, subgroups of three to five individuals often travel together shoulderto-shoulder in a tight rank formation (see, e.g., fig. 228 in Leatherwood et al. 1982). Second, within these groups, individuals are recognizable by their various color patterns (Miyazaki and Perrin 1994; R.L.P., pers. obs.), a useful trait for coordinating cooperative foraging and preventing individual members from "cheating." Third, S. bredanensis readily shares large individual prey they have captured. The occurrence of small, wellcoordinated foraging groups with individually recognizable members that share prey is, in general, indicative of a high level of cooperation (Connor and Norris 1981).

Finally, as a possible morphological adaptation to preying upon mahimahi, we would like to point out that the need to restrain a large, vigorous, and slippery prey such as an adult mahimahi may have led to the development (or perhaps retention) of the uniquely rugose teeth that give the rough-toothed dolphin its common name.

We thank W. F. Perrin for pointing out that rugose teeth are plesiomorphic in odontocetes; Chico Gomez ably assisted us in the field.

\section{Literature Cited}

$\mathrm{Au}, \mathrm{D}$. W. 1991. Polyspecific nature of tuna schools: Shark, dolphin, and seabird associates. Fish. Bull., U.S. 89:343-354.

Barros, N. B., E. C. M. Parsons, and T. A. Jefferson. 2000. Prey of offshore bottlenose dolphins from the South China Sea. Aquat. Mamm. 26:2-6.

Brower, K., and W. R. Curtsinger. 1979. Wake of the whale. Friends of the Earth, New York.

Clarke, M. R. 1986. Cephalopods in the diet of odontocetes. Pages 281-321 in M. M.
Bryden and R. J. Harrison, eds. Research on dolphins. Clarendon Press, Oxford.

Connor, R. C., and K. S. Norris. 1981. Are dolphins reciprocal altruists? Am. Nat. 119:358-374.

Defran, R. H., and K. Pryor. 1980. The behavior and training of cetaceans in captivity. Pages 319-362 in L. M. Herman, ed. Cetacean behavior: Mechanisms and functions. John Wiley, New York.

Ferrero, R. C., J. Hodder, and J. Cesarone. 1994. Recent strandings of rough-toothed dolphins (Steno bredanensis) on the Oregon and Washington coasts. Mar. Mamm. Sci. 10:114-116.

Hunter, J. R., and C. T. Mitchell. 1966. Association of fishes and flotsam in the offshore waters of Central America. Fish. Bull., U.S. 66:13-29.

Leatherwood, S., R. Reeves, W. F. Perrin, and W. E. Evans. 1982. Whales, dolphins and porpoises of the eastern North $\mathrm{Pa}$ cific and adjacent Arctic waters. NOAA Tech. Rep. NMFS Circ. 444.

Miyazaki, N., and W. F. Perrin. 1994. Rough-toothed dolphin-Steno bredanensis (Lesson, 1828). Pages 1-21 in S. H. Ridgway and R. J. Harrison, eds. Handbook of marine mammals. Vol. 5. The first book of dolphins. Academic Press, London.

Palko, B. J., G. L. Beardsley, and W. J. Richards. 1982. Synopsis of the biological data on dolphin-fishes, Coryphaena bippurus Linnaeus and Corypbaena equiselis Linnaeus. NOAA Tech. Rep. NMFS Circ. 443.

Perrin, W. F., and W. A. Walker. 1975. The rough-toothed porpoise, Steno bredanensis, in the eastern tropical Pacific. J. Mammal. 56:905-907.

Shallenberger, E. D. 1981. The status of Hawaiian cetaceans. U.S. Department of Commerce, National Technical Information Service PB82-109398. 